\title{
Sub-regional Maritime Security Challenges: A Cooperative Approach
}

Udai Rao*

\section{Abstract}

The Indian Ocean Region has today emerged as the most important region of strategic concern. With India and China trying to establish their clout over this region and using it to propel themselves to the Superpower title, Indian Ocean becomes an interesting site for maritime security studies. This article attempts to trace the different areas of concern for all the stakeholders involved in the management of this sub-regional maritime security. Maritime cooperation and security would ensure secure and safe seas which in turn would allow resurgence of our economies in a mutually beneficial manner. The subregional grouping with Maldives and Sri Lanka has to transcend beyond the South Asia sphere, encompassing Seychelles and Mauritius and would be a 'Bottom Up Approach' to shaping the maritime strategic environment in the Indian ocean.

Keywords: Indian Ocean, Maritime Security, Sub-regional, Maritime Security, Small Island Developing States

The Indian Ocean has today emerged as the centre of gravity of the world in the maritime domain. The eminent US Naval strategist Alfred Thayyar Mahan had said as far back as 1890 that "Whoever controls the Indian Ocean will dominate Asia. This ocean is the key to the Seven Seas. In the $21^{\text {st }}$ century the destiny of the world will be decided in its waters". India's centrality in the Indian Ocean needs no emphasis. The Indian Peninsula juts into the North Indian

* Indian Navy, India; udair1@gmail.com 
Ocean like a springboard, dividing it into two almost equal halves. The Indian Ocean has the Asian landmass as a rooftop and is land locked from three sides with access largely from the Southern approaches and through the choke points of Hormuz, Suez Canal, Gulf of Aden, Straits of Malacca, Sundastraits and Lombok straits. Through these choke points pass the East-West Sea Lanes of Communications (SLOCs) which are the economic lifelines of the world, passing close to our shores and putting us in a very vantage position.

The Indian Ocean thus links the Atlantic and the Pacific Oceans. What is more important is that $66 \%$ of the world's oil, $50 \%$ of the world's container traffic and 33\% of the world's general cargo passes through the Indian Ocean. A significant point is that $80 \%$ of the world's trade which transits the Indian ocean is extra-regional in nature. This means that any disruption in the free flow of trade through the Indian Ocean, can have a catastrophic impact on the global economy. More importantlyover $90 \%$ of our trade by volume $^{1}$ including crude oil passes through the same SLOCs, so vital for our economic and energy security. To that extent India, washed as she is by three oceans, is actually an island country.

India sharesmaritime boundaries with seven countries, namely Pakistan, Bangladesh, Myanmar, Thailand, Indonesia, Sri Lanka and the Maldives; the last two being true island countries. In recent times the term 'Small Island Developing States' (SIDS)is increasingly being heard on the world stage. Sri Lanka and Maldives belong to that category. Therefore if one were to talk of a sub-grouping under SAARC, India and the two island states of Sri Lanka and Maldives are perfect candidates for the sub-regional maritime grouping as we have much in common. Sri Lanka is India's closest maritime neighbour, connected by an umbilical cord, the Ram Sethu, but separated by the Palk Bay, both physically and metaphorically due to the fishermen's problem. The Maldives which consist of about 1200 islands is about $400 \mathrm{NM}$ from India and despite historically good relations, some irritations have crept into our relationship of late.

The tyranny of geography fortunately does not affect island states as it does the land states. The seas offer great connectivity facilitated by the principle of 'Mare Liberum' or the 'Freedom of 
the Seas', unlike on land. Therefore while land states may look at grouping based on contiguous neighbourhood, island states are not so bound. The seas have a transnational nature about them, permitting distant countries with even a modicum of sea faring skills to be neighbours.

By extension the question that arises next is why should the grouping be restricted to only countries under SAARC? The other prominent Indian Ocean island states of Seychelles and Mauritius may not be a part of SAARC, but the maritime medium makes them our neighbours and we need to transcend the South Asian sphere to connect across the global commons. After all India, Sri Lanka, Maldives, Seychelles and Mauritius have a lot in common in terms of history, culture, ethnicity, religion, commerce, Diaspora etc. These four island countries straddle the SLOCs in the Indian Ocean and also geo strategically dominate the approaches to the North Arabian Sea as also India. Unfortunately due to our continental mindset and perpetual obsession with Pakistan, we have neglected these maritime neighbours for far too long, much to our own detriment. Consequently extra regional powers like China have warmed up to them for their own strategic interests.

In its quest to be a regional power India has always considered itself as a 'Net Security Provider' in the Indian Ocean Region(IOR)as highlighted by former Prime Minister Manmohan Singh a few years ago. Mr. Narendra Modi soon after taking over as Prime Minster of India articulated the 'Act East Policy' which is our very own pivot. India now sees the Indo - Pacific as an integrated entity. PM Narendra Modi realises that his development agenda, on the basis of which he came to power, 'Make in India' campaign, 49\% FDI move and Blue Economy are all dependent on the safe seas. All most all of Modi's out visits therefore have had a strong maritime element with the obvious aim of shaping our maritime domain and the outcome documents are also replete with references to maritime security, maritime cooperation and china's intransigence in the South China Sea. PM Modi's visit to the Indian Ocean island countries of Seychelles, Mauritius and Sri Lanka earlier this year has to be seen in this light. Maldives unfortunately had to be excluded due to the treatment meted out to the former Maldivian president Nasheed. 
Economy and Security are two sides of the same coin. Maritime security is like an insurance policy for national development. Therefore we need to build our own 'String of Pearls' to shape the security construct of our neighbourhood for mutual benefit. This can minimise the footprint of an extra regional power like China and make the area a secure and developing neighbourhood, where we resolve issues peacefully through dialogue, making India a fulcrum of stability.

India, Sri Lanka and Maldives launched the 'Trilateral Cooperation in Maritime Security' in October 2011 at the first NSA-level Trilateral Meeting on Maritime Security Cooperation in Maldives. ${ }^{4}$ Seychelles and Mauritius are all set to include in the talk as they currently have observer status. This is indicative of the fact that the grouping with Sri Lanka and Maldives would be incomplete without Seychelles and Mauritius because of the common challenges we face at sea. The former NSA Shivshankar Menon had called the five countries the 'Indian Ocean $5^{\prime}$-Nevertheless due to the scope that has been set out for the author, this article will deal largely with the trio of India, Sri Lanka and Maldives with brief references to Seychelles and Mauritius where pertinent.

When nation states decide to form a grouping or sub-grouping, they naturally would have to consider the environment including threats, challenges, opportunities, interests etc. The Indian Ocean which has an area of 68.5 million sq. $\mathrm{km}$, is home to many of these as elaborated below.

\section{Threats at Sea}

The biggest threat to maritime security in the Indian Ocean today is not from any conventional war, but from unconventional or asymmetric threats. Maritime terrorism tops the list, with piracy especially off Somalia, coming next. Smuggling, poaching, drug trafficking, illegal migration, movement of suspicious vessels, cargo and crew; people smuggling, gun running and narco-terrorism are all serious security threats too, since the machinery and network used for them could also be used for maritime terrorism as in the 1993 Mumbai blasts. 


\section{Maritime terrorism}

We live in a troubled neighbourhood. Pakistan's state sponsored terrorism is well known to need any recounting here. In the last few years Pakistan has been channelling some of its nefarious activities to India through neighbourhood. A Pakistani diplomat based in Sri Lanka was reportedly involved in trying to ferment problems in the Southern States of India in 2014 as reported by the media. Maldives has in recent years become increasingly radicalised with the active support of Pakistan. The problem of Islamic State of ISIS it appears is here for a long haul and could well singe us. Only last year the AlQaeda leader Ayman Al Zawahiri had threatened to raise the flag of jihad in the Indian subcontinent, targeting India, Myanmar and Bangladesh. Again in 2014, Taliban fightershad stormed the Karachi naval base and even tried to hijack a naval vessel 'Zulfiqar'to attack US Navalships, something which could be attempted against us too. All this is happening even as the US prepares to leave Afghanistan and is shifting to the Pacific through the rebalancing strategy under Obama administration which would create a vacuum to the North West of our country, with consequences for India. It is a wellestablished fact that Al Qaeeda, Taliban, Lashkar -e -Taiba ( LET) etc. have all got sea going skills and could team up with other like-minded organizations to carry out dastardly attacks at / from the sea.

As far as maritime terrorism is concerned we have indeed learnt the hard way. The 1993 Mumbai blasts for which arms and ammunition came across the seas may be a distant memory, but the 26/11 Mumbai attacks was definitely a more traumatic and humiliating experience- a 'Maritime Kargil' so to speak. More recently we have had the Pakistani boat incident which blew itself up off Porbandar on 31 Dec 2014and few months ago an Iranian boat ${ }^{11}$ with Pakistani crew was apprehended off Kerala under suspicious circumstances.

\section{Piracy}

Piracy off Somalia which started in 2008is thankfully on the wane after peaking in 2011 largely due to the efforts of multinational navies and embarkation of armed guards on merchant ships. 
Several Indians have been held hostage by the pirates, causing anguish to them and their families back home. The Indian Navy has constantly had a ship on patrol off Somalia since 2008 and has rescued mariners of several nationalities; not just Indians. Pirates have operated over a large swath of the ocean, striking as far as off Seychelles and Mauritius and even India's Lakshadweep \& Minicoy Islands. The menace of piracy has had a negative impact on the security, fishing and tourism industries of these island countries.

\section{The Dragon in the Indian Ocean}

But the biggest long term threat in the Indian Ocean is China. If anything has rekindled our interest in 'matters maritime', it is the surge of the PLA Navy into the Indian Ocean in the last decade or so. China's interest in the Indian Ocean stems largely from her desire for super power status and the fact that she is today the world's second largest economy. To fuel this economy, China imports $60 \%$ of her crude oil requirements from West Asia and West Africa through the choke points of Gulf of Aden, Hormuz, Malacca Straits, Cape of Good Hope etc. India due to her geo strategic position dominates these SLOCs and could interdict it in the event of a standoff with China. China, therefore, has been shaping the environment by assisting countries along the West Asia - Malacca axis.

\section{String of pearls strategy}

At the outset China has built ports and infrastructure at Gwadar in Pakistan, Hambantota in Sri Lanka and Kyaukpyu in Myanmar in what has come to be known as 'String of Pearls Strategy'. The rail, road and overland pipe network being built from Gwadar to Kashgar in Xinjiang province of China and the overland pipeline from Kyaukpyu in Myanmar to Kunming in Yunnan province would enable China to pump oil from West Asia directly to its hinterland thus avoiding the long logistic tail via the Indian Ocean and the vulnerable Malacca straits. She would also be able to use these channels to export finished products. Her presence in Hambantota and Colombois akin to a Southern border being opened up for India. With footholds in the Arabian Sea (Gwadar), Bay of Bengal (kyaukpyu) and Hambantota, China automatically 
becomes an Indian Ocean power. PM Modi's visit to Vietnam and Japan and efforts to cement relations with them are obviously meant to return china's favour in her own backyard.

\section{Anti-Piracy Task Force}

It was, however, the advent of piracy off Somalia in 2008 that was the laboratory for China's surge in to the Indian Ocean. China first sent its three ship Anti-Piracy Task Force to patrol off Somalia in 2008 and today the 19th Task Force is on station. This has been an excellent training ground for an emerging Blue Water PLA Navy. The ships stayed for several months at a time in the area, with the accompanying tanker providing logistics. The ships have also called at various ports in the region such as Seychelles, Aden, Oman, Djibouti, Saudi Arabia etc. for logistics. The Chinese have also used this opportunity to hold joint exercises and other aspects of maritime diplomacy with regional navies. Seychelles in fact had in 2012 reportedly offered basing facilities to China to support operations in the area ${ }^{16}$. China of course has denied any such plans. China thus has developed a legitimate and permanent naval presence in the IOR.

\section{Submarine intrusions into the Indian Ocean}

Simultaneously the US Navy had reported Chinese submarine intrusions into the Indian Ocean and later the Indian Navy too started reporting forays by Chinese submarines into the IOR. But it was the well publicised visits of a conventional submarine and later a nuclear submarine to Colombo in 2014 and more recently a Yuan class submarine's visit to Karachi that has sent alarm bells ringing in Delhi which sees it as a subtle message from China of its growing maritime prowess.

\section{New maritime silk route}

But the Chinese masterstroke came in 2014 with the announcement of a $\$ 40$ billion new Maritime Silk Route (NMSR) which envisages the building of ports, marine infrastructure, SEZ etc. from China all the way to Europe along the seashore. Although projected as an economic initiative, it has underlying military and strategic objectives with serious implications for India. Sri Lanka, Maldives, Seychelles, Mauritius and several other countries have all signed 
up for NMSR. These countries lack resources and therefore have opted to do what is best for them. India's coffers may not be overflowing currently, but it can still hold its own with some smart moves and need not compete with China.

India's Ministry of External Affairs (MEA) last year announced Project Mausam, presumably as an answer to China's NMSR, which is a throwback to our monsoon driven seafaring traditions. The details are very sketchy and how it will translate to present day maritime economics is not very clear. The MEA needs to explain this to our people and our neighbours so that the project can indeed take off.

\section{Blue Economy}

In the last few years the concept of a Blue Economy has emerged largely from Small Island Developing States (SIDS) who find that the seas are more relevant to them than the 'Green Economy' being talked about by larger countries. This is the sustainable development of living and nonliving resources from the seas in an integrated manner and includes fishing, harbours, shipping \& cargo; oil \& gas exploration, ship building, sea bed mining, marine technology, marine tourism etc.

\section{Maldives}

Our geography and our alacrity have always ensured that we have always been first responders whenever Maldives has faced a crisis. In 1988, the Indian Navy led by INS Godavari successfully averted a coup in Maldives in an operation code named 'Operation Cactus'. In 2004, after the Tsunami, the Indian Navy was quick on the scene to help Maldives, Sri Lanka and several other countries. China, surprisingly was conspicuous by its absence. In 2015, when Maldives faced a drinking water crisis, the Indian Air Force (IAF) and our Navy swung into action, although China too did fetch up, albe it a little later.

The increasing radicalization of Maldives, President Yameen's proChina tilt, the GMR fiasco, the arrest of former president Nasheed etc. are not in our favour. China's investment in upgradation of Maldives International Airport, building of a bridge between Male and Hulhule, housing projects etc. are worrying Delhi. Recently 
Maldives has passed laws allowing foreigners to buy land provided they invest $\$ 1$ billion and reclaim $70 \%$ of the land from the sea. China has the money and the expertise to reclaim land, so this largesse is perhaps mostly intended for China and needs careful watching. Maldives incidentally has the largest number of tourists from China at 400,000 per year which indicates their warming ties.

\section{Sri Lanka}

Turning to Sri Lanka, the Tamil Nadu(TN) factor and its objections to training of Sri Lankan military personnel in India and India's principled stand on the UN resolutions on Sri Lanka's war crimes have all indirectly helped China and Pakistan, who have obviously capitalized on it. While we complain of China's investment in Hambantota the fact is that it was first offered to India and we kept sitting on it and did not do much to involve our private companies. Similarly the control of Trincomalee was first offered to New Delhi in early 2000but TN and LTTE were possibly the inhibiting factors. Sri Lanka is bound to have a soft corner for China considering that in the final stages of its war against LTTE it was China that came to Sri Lanka's rescue, when India was handicapped in providing frontline equipment due to the $\mathrm{TN}$ factor.

After Maithripala Sirisena took over as President of Sri Lanka in 2015 and after PMModi's recent visit to Colombo, the relationship has regained some leverage. India has agreed to help make Trincomalee, with its 99 Second World War oil storage tanks, a petroleum hub. There is talk of India removing wrecks from Kankesanturai harbour in Northern Jaffna and making it navigable once again. Ferry services between Colombo and Tuticorin in Tamil Nadu could also be started.

As regards the Palk Bay and Katchativu, there are many number of views. The Centre has however told the Supreme Court that Katchativu was never ceded to Sri Lanka and by implication there is no going back on Katchativu. Our side of the International Maritime Boundary Line(IMBL) has been overfished due to the bottom trawling method of fishing adopted by TN fishermen. On the other hand, the Sri Lankans have adopted better fishing practices and the suspension of fishing in restricted areas during 
the Eeelam war has helped the fish population multiply. Legally and diplomatically our fishermen cannot cross the IMBL into Sri Lanka. The only way out is to encourage them to shift from traditional fishing to deep sea fishing. In the interim we need to look at fish farming in the Palk bay and Gulf of Mannar. Licensed fishing in Sri Lankan waters with the latter's approval could also be explored. Till then the fishing wars have the potential to create diplomatic issues every few months and would be the biggest fishbone in our relations.

But it must also be said that Sri Lankan deep sea fishing vessels have also been intercepted fishing in India's EEZ both off the West and East coasts, though we do not go about shooting them, unlike Sri Lanka does. Further, Sri Lanka has permitted Chinese trawlers to carry out licensed fishing in its EEZ, which has implications for India. Also over 30\% of India's cargo is transhipped at Colombo at the Chinese owned container terminals which poses serious security concerns. Sri Lanka also needs to monitor the numerous Private Maritime Security Companies (PMSC) with their floating weapon armouries which have sprung up after the advent of piracy off Somalia and operate from Colombo.

\section{Building Bridges across the Oceans}

In the last few years the term 'Maritime Cooperation' has become a buzzword during discussions between leaders and in the outcome documents of their visits, as also in bilateral and multilateral fora. This is on account of the increasing importance of the seas. Cooperation at sea becomes necessary due to the sheer size and expanse of the maritime domain, due to which no nation has the resources to go it alone. The maritime domain offers great connectivity as mentioned earlier and there are no fences at sea unlike on land. The freedom of the seas allows us to cooperate keeping sovereignty issues in mind, i.e., without crossing the 12 NM territorial waters limits, if so required. The coming together of multinational navies to fight piracy off Somalia is a prime example of maritime cooperation.

There is tremendous scope for maritime cooperation between India, Sri Lanka, Maldives, Seychelles \&Mauritius as elaborated below. The island states are still developing nations and require all the 
help they can get from India. They will try and play India and China against each other for their individual benefit and will have differences of opinion as well. But their sensibilities need to be respected. We however need to be alert so that anything which affects our national interest, especially where China and Pakistan are concerned are suitably addressed. Indeed, New Delhi should not force countries to choose between India and China. India's benign nature is there for all to see and China is perhaps its own biggest enemy. New Delhi needs to highlight the peaceful resolution of the Indo-Bangladesh IMBL problem through the International Tribunal on the Law of the Sea (ITLOS) in 2014 even though we lost a little more EEZ than what we had expected. In contrast, China's disputes and aggressive stance in the South China Sea speaks for itself. A common complaint that is often heard is that India is slow in implementing projects, which unfortunately is true. India needs to act on our promises quickly like China.

\section{Maritime domain awareness (MDA)}

A pre-requisite for dominating the oceans is Maritime Domain Awareness (MDA)or situational awareness at sea. This has become critical after $9 / 11$ and 26/11. The idea being to map all activities at sea so that one can decide what is normal and / or abnormal and thereby tackles illegal or suspicious activities. This can be done by a plethora of platforms and sensors such as ships and aircraft, Satellites, Unmanned Aerial Vehicles (UAVs),Long Range Information and Tracking (LRIT) which is satellite based, Automatic Identification Systems(AIS) which is V/UHF enabled, Coastal Surveillance Radars, intelligence inputs etc. which are fused together to present a coherent picture to make the seas translucent.

During PM Modi's recent visit to Seychelles he commissioned a network of coastal radars. Seychelles will ultimately have eight radars, Mauritius eight, Maldives ten and Sri Lanka six radars. This network of radars would share sensor data with participating countries and would be linked with Indian Joint Operations Centres (JOCs) at Mumbai, Vishakhapatnam, Kochi and Port Blair and the National Command, Control, Communication and 
Intelligence facility (NC3I) at Delhi, thus enhancing our maritime domain awareness.

India has also entered into an agreement with 24 countries to share white shipping information on merchant ships, their cargo and crew. The idea is to nab rogue ships carrying suspicious cargo or crew to ports of participating nations including in Seychelles, Mauritius, Maldives and Sri Lanka before they can strike. Merchant ship information obtained from Long Range Information and Tracking (LRIT) and Automatic Identification System (AIS) would also be shared. The 'Trilateral Maritime Security Cooperation Initiative 'with Sri Lanka and Maldives and which is expected to include Seychelles and Mauritius soon, will also contribute to enhancing our MDA.

\section{Humanitarian assistance and disaster relief (HADR)}

It appears that navies are made for providing humanitarian assistance and disaster relief. The Indian navy's response after the 2004 Tsunami was indeed exemplary. This quick response earned India and its Navy worldwide kudos. More recently the Indian Navy carried out searches for the missing Malaysian aircraft $\mathrm{MH}$ 370 in the waters of the Andaman Sea and Bay of Bengal. India's quick response during the drinking water crisis in Maldives in early 2015 has been well appreciated. Further during the recent crisis in Yemen when people had to be evacuated; the Indian Navy, a few of our merchant ships and the Air Force all swung in to action, rescuing not just Indians, but people of several nationalities.

\section{Port visits / joint exercises}

Ships of the Indian Navy routinely visit the four island countries, making port visits and conducting joint exercises to inspire confidence and build inter-operability to tackle crises whenever they occur. The Indian coast guard conducts joint exercises with the Coast Guards of Sri Lanka and Maldives called 'DOSTI' which includes Search and Rescue (SAR), marine oil spill response, medical evacuation etc. Similarly the Indian Navy carries out joint exercises with the Sri Lankan Navy called 'SLINEX'. 


\section{EEZ patrol}

Countries like Maldives, Seychelles and Mauritius have large Exclusive Economic Zones (EEZs) of 1.2 million sq. km, 1.3 million sq. $\mathrm{km} \& 1.27$ million sq. $\mathrm{km}$ respectively. However, they lack the resources to keep such large EEZs under surveillance against threats outlined earlier. Indian ships and aircraft often carry out EEZ patrol in the EEZs of Seychelles, Mauritius and Maldives at their invitation which due to the transnational nature of the seas adds to our security.

\section{Hydrographic assistance}

India with its own hydrographic organization has been helping Maldives Seychelles, Mauritius etc. map their oceans for safe navigation and exploitation of sea resources. The United Nations Conference on the Laws of the Seas (UNCLOS) and the impending expansion of the EEZ from $200 \mathrm{NM}$ to $35 \mathrm{O} \mathrm{NM}$ depending on the extension of the continental shelf underwater, has been a catalyst and has seen nations hurrying to map their oceans. During Modi's visit to Seychelles, an agreement was signed for cooperation in hydrographic surveys and joint development of navigation charts ${ }^{43}$.

\section{Ocean science technology}

India leads the region with many institutes on ocean science which could help the island nations. The Ministry of Earth Sciences (MoES) has a number of organizations such as the Centre for Marine Living Resources and Ecology, Kochi; Centre for Integrated Coastal and Marine Area Management, Chennai; National Centre for Ocean Technology, Chennai; and National Centre for Antarctic and Ocean Research, Goa which could help the island states address issues such as sustainable fishing, climatology, oceanography, meteorology, global warming, natural disasters etc.

\section{Cooperation in Blue Economy}

India with its huge scientific manpower pool and large scientific and industrial base is well suited to cooperate with the four island countries in oil and gas exploration, sea bed mining (India is a pioneer investor in Southern Indian ocean), ship building, ocean engineering, building of maritime infrastructure etc. and in turn could benefit in deep sea fishing and marine tourism from them. 
India needs more civilian maritime projects and needs to provide not just patrol ships but civilian ships of about 1000 tons with amphibious capability for better inter-island connectivity of these nations. New Delhi also needs to encourage private companies like Larsen \& Toubro ( $L \& \mathrm{~T}$ ) etc. to compete for maritime projects in these countries in competition with China Harbour Engineering Company (CHEC) and other Chinese companies. It is interesting to note that while India is building medium sized Offshore Support Vessels (OPVs) for Sri Lanka, the latter in turn is building small interceptor craft for the Sagar Prahari Bal of the Indian Navy.

\section{Capacity building}

As far as capacity building is concerned, it is mostly about hardware, equipment and infra structure. During PM Modi's recent Indian Ocean visit he handed over a new Indian built patrol vessel to Mauritius called 'Barracuda' and promised a second Dornier aircraft to Seychelles. Earlier in 2014 a patrol vessel called 'Constant' and Indian built Dhruv helicopters were handed over to Maldives. The PM has spoken about building infrastructure on Assumption Island in Seychelles and Agalega Island in Mauritius which could be a strategic asset for us especially in presence missions and in enhancing our MDA.

\section{Training}

For the last several decades India has trained a large number of naval officers and sailors from countries all over the globe in abinitio courses as also advanced courses. The training is of a very high quality and at a fraction of the cost of that offered by Western countries. This has seen many countries including Seychelles, Mauritius, Maldives and Sri Lanka opt for Indian training. In fact Sri Lanka is the beneficiary of the largest number of training slots from India in recent times. The navy has undertaken diving and special forces training and training for Visit, Board, Search and Seizure (VBSS ) operations for some of the island countries lately .

\section{Maritime Multilateralism}

India is a member of the 20 nation multilateral organization 'Indian Ocean Rim Association' (IORA)based in Mauritius which deals with economic, cultural and political issues and indeed must also 
address maritime issues more effectively. Sri Lanka, Seychelles and Mauritius are also members of the IORA(China is a dialogue partner). There is however a need for India and other nations to infuse fresh energy into IORA to achieve comprehensive maritime security and economic development in the Indian Ocean. The Indian Navy launched the Indian Ocean Naval Symposium (IONS) in 2008 as a construct to enhance maritime cooperation among the 35 member navies in the Indian Ocean Region. The aim was to promote shared understanding of maritime issues facing littoral nations and formulate strategies to enhance regional maritime security. India is also a founding member of the UN sponsored 'Contact Group on Piracy off the Coast of Somalia'(CGPCS) and has made useful contribution in tackling piracy issues. The four island countries are also members of the CGPCS mechanism. The region also has a multilateral naval construct called 'MILAN'. It is a biennial event to enhance regional cooperation and is conducted at Port Blair. The last was held in Feb 2014 where 17 countries participated including the four island states. The Indian Navy will host its second International Fleet Review (IFR) from 04-08 Feb, 2016 at Vishakhapatnam to promote maritime cooperation and friendship. The slogan of the IFR is 'United through Oceans' and will showcase ships from over 60 nations, including the four island nations. With India, Sri Lanka, Maldives, Mauritius and Seychelles being members of several multilateral maritime organizations, there is much we can do together for security and cooperation at sea.

\section{The Way Ahead}

It is very clear that we need to build maritime bridges with our island neighbours to better engage them. We have been slow due to our lack of a maritime vision. Maritime issues including maritime cooperation can be handled better with a strong Maritime Governance structure at Delhi. In this respect the much overdue National Maritime Authority (NMA) promised by the Modi government in June 2014 needs to be implemented as early as possible. This would bring about much needed coordination amongst the various maritime stake holders so that they act in complete synergy which would actually help PM Modi's 'Maritime Outreach' in big way. The NMA would help us script a more 
robust maritime vision and help us draw up a 'National Maritime Strategy for India' which hopefully would incorporate a 'Maritime Counter-Terrorism Strategy' and a 'Strategy for the Indian Ocean'.

Maritime cooperation and security would ensure secure and safe seas which in turn would allow resurgence of our economies in a mutually beneficial manner. The template of land groupings may not necessarily apply to island states. The sub-regional grouping with Maldives and Sri Lanka has to transcend beyond the South Asiasphere, encompassing Seychelles and Mauritius and would be a 'Bottom Up Approach' to shaping the maritime strategic environment in the Indian ocean.

\section{References}

After Mauritius, India to export warships to Sri Lanka. (2014, December 20). Times of India. Retrieved from http:// timesofindia.indiatimes.com/ india/After-Mauritius-India-to-exportwarships-to-Sri-Lanka/articleshow/45585454.cms

Al Qaeeda, Taliban \& LET have sea going skills: the attacks on USS Cole, Karachi and the 2008 Mumbai attacks are proof enough.

Al-Qaeda chief Zawahiri launches al-Qaeda in South Asia. (2014, September 04). BBC. Retrieved May 08, 2016, from www.bbc.com/news/world-asia-29056668

Ashay, A. (2015, July 26). String of Pearls: India and the Geopolitics of Chinese Foreign Policy. E-International Relations. Retrieved May 14, 2016, from http://www.e-ir.info/2015/07/26/string-of-pearls-indiaand-the-geopolitics-of-chinese-foreign-policy/

Basheer, K. (2013, June 24). Chinese fishing off Sri Lanka hits Indian fish workers. Business Line. Retrieved May 30, 2016, from http:// www.thehindubusinessline.com/economy/agri-business/chinesefishing-off-sri-lanka-hits-indian-fishworkers/article4846983.ece

Boehler, P. (2015, January 21). 'It's the Gucci handbag of holidays': Maldives tops Chinese. South China Morning Post. Retrieved June 16, 2016, from http://www.scmp.com/ news/ china/ article/ 1688260/chinese-tourists-increasingly-be-beside-seaside-exotic-islandnation

Brewster, D. (2013, November). India: Regional net security provider. Gateway House: Indian Council on Global Relations. Retrieved May 10, 2016, from http://www.gatewayhouse.in/india-regional-netsecurity-provider/ 
Brewster, D. (2014). Operation Cactus: India's 1988 intervention in the Maldives, in India's Ocean: the story of India's bid for regional leadership. Retrieved from http://pragati.nationalinterest.in/ 2014/04/operation-cactus-indias-1988-intervention-in-the-maldives /

Brewster, D. (2014).India's Ocean: The Story of India's Bid for Regional Leadership. Routledge. London.

Brewster, D. (2014, March 13). Www.lowyinterpreter.org/.../India's-ownstring-of-pearls-Sri-Lanka-Maur. The Interpreter. Retrieved from https://www.lowyinstitute.org/the-interpreter/indias-own-stringpearls-sri-lanka-mauritius-seychelles-and-maldives? collcc $=738849184$

Coast Guard seize 'suspicious' vessel off Kerala coast. (2015, July 06). The Indian Express. Retrieved June 12, 2016, from http:/ /indianexpress.com/article/india/india-others/suspiciousvessel-caught-off-kerala-coast/

Contact Group on Piracy off the Coast of Somalia. Retrieved from https://en.wikipedia.org/wiki/Contact_Group_on_Piracy_off_the_C oast_of_Somalia

Das, K. (2014, June 12). Pakistani Consulate In Colombo Was Being Used To Target South India. In News. Retrieved May 23, 2016, from https:/ /inserbia.info/today/2014/06/pakistani-consulate-incolombo-was-being-used-to-target-south-india/

Das, M. (2015, January 02). Pakistani Boat Blows Itself Up at Sea Off Porbandar. NDTV. Retrieved July 02, 2016, from http:/ / www.ndtv.com/india-news/pakistani-boat-blows-itself-upat-sea-off-porbandar-721686

Dhowan, R. K. (2014). Indian Ocean region: emerging strategic cooperation, competition and conflict scenarios [key note address]. USI journal, CXLIV (598), 544-545.

Dixit, S. (2014, March 07). Seychelles, Mauritius join Indian Ocean maritime security group. The Hindu. Retrieved May 18, 2016, from http://www.thehindu.com/news/national/seychelles-mauritiusjoin-indian-ocean-maritime-security-group/article5758402.ece

Erickson, A. S., Strange, A., \& Strange, A. (2015). China's Global Maritime Presence: Hard and Soft Dimensions of PLAN Antipiracy Operations. China Brief, 15(9). Retrieved June 15, 2016, from http:// www.jamestown.org/ programs/ chinabrief/single/ ?tx_ttnews [tt_news] $=43868 \& \mathrm{cHash}=8 \mathrm{a} 087 \mathrm{cf} 151074 \mathrm{eed} 214 \mathrm{dfe} 5 \mathrm{bba01edbf \# .V4DFz}$ FL7AdU

Galaxy. (2011, Oct 18). Indian navy to buy 80 interception boats from Sri Lankan builder. Message posted to http://defenceforumindia.com/ forum/threads/indian-navy-to-buy-80-interception-boats-from-srilankan-builder.26250/ 
Ghosh, P. K. (2012). Indian Ocean naval symposium: uniting the maritime Indian Ocean region. Strategic Analysis. 36(3). 352-357.

Gosh, P. K. (2015, July 06). Game Changer? Chinese submarines in the Indian Ocean. The Diplomat. Retrieved May 09, 2016, from thediplomat.com/.../game-changers-Chinese-submarines-in-theIndian-ocean.

Government of India, Indian Navy. Piracy off Somalia [Press release]. Retrieved June 21, 2016, from indiannavy.nic.in/ operations

Government of India, Ministry of External Affairs. (n.d.). Trilateral Maritime Security Initiative [Press release]. Retrieved March 12, 2016, from www.mea.gov.in/in-focus-article.htm?23037/NSA level meeting on trilateral Maritime Security Cooperation between India Sri Lanka and Maldives

Gunasekera, R. (2015, Sep. 25). India warns Sri Lanka over maritime security concerns. Economy Next. Retrieved from http:// www.economynext.com/India_warns_Sri_Lanka_over_maritime_sec urity_concerns-3-3078-10.html

India Reinforces Maritime Domain Awareness but Challenges Remain. (2014, December 02). Centre for International Maritime Security. Retrieved June 25, 2016, from http://cimsec.org/india-reinforcesmaritime-domain-awareness-challenges-remain/13789

India to Keep an Eye on Shipping in Indian Ocean. (2015, May 11). World Maritime News. Retrieved June 19, 2016, from http:// worldmaritimenews.com/archives/160479/india-to-keep-an-eye-onshipping-in-indian-ocean/

Indian Ocean rim association. (2015, Oct. 31). Retrieved from www.iora.net

International Fleet Review 100 ships from 60 nations: Vizag braces for its biggest. (2014, Jul. 26). The Indian Express.

Jayanti, S. (2015, Jun. 18). Views from India's smaller maritime Neighbours. CSIS. Retrieved from http/amti.csis.org/views-fromIndia's-smaller-maritime-neighbours /

Khurana, G. (2015, May 21). India's Yemen evacuation: an evolving doctrine. NMF issue brief. Retrieved from http:// www.maritimeindia.org/View\%20Profile/Maritime\%20Perspective\% 2015.pdf

Malaysia lauds Indian navy for MH370 search efforts. (2015, March 12). The Economic Times. Retrieved May 30, 2016, from http:// economictimes.indiatimes.com/news/international/world-news/ malaysia-lauds-indian-navy-for-mh370-searchefforts/articleshow/46539888.cms

Maldives: Upgradation of Maldives airport. (n.d.). Haveeru Online. Retrieved from www.haveeru.com.mv/malehulhule_bridge 
Mohan, C. R. (2015, Mar. 12). Narendra Modi and the ocean: maritime power and responsibility. The Indian Express. Retrieved from http:/ /indianexpress.com/article/opinion/columns/modi-and-theocean-maritime-power-and-responsibility/

Narula, K. (2015, Jan. 06). Drinking water crisis in Maldives: India leads the way. NMF Commentary. Retrieved from www.maritimeindia.org/ archives.

Nkala, O. (2015, March 20). India developing network of coastal radars. Defense News. Retrieved May 15, 2016, from http://www.defensenews.com/story/defense/naval/2015/03/20/in dia-seychelles-coastal-radar-china-modi-indian-ocean/25084237/

Pandit, R. (2014, Jun. 10). Apex maritime authority for coastal security. The Economic Times. Retrieved from http:// economictimes.indiatimes.com/news/politics-and-nation/ apexmaritime-authority-for-coastal-security/articleshow/36342504.cms

Pillalamarri, A. (2014, Sep 18) Project Mausam. The Diplomat. Retrieved June 03, 2016, from thediplomat.com/.../project-Mausam-India'sanswer-to-China's-maritime-sil...

Radhakrishnan, R. (2011, September 23). India, Sri Lanka conduct naval exercises. India, Sri Lanka conduct naval exercises. Retrieved from http://www.thehindu.com/news/international/india-sri-lankaconduct-naval-exercises/article2478888.ece

Rahman, M. (2012, March 22). Chinese plans in Seychelles revive Indian fears of encirclement. The Guardian. Retrieved May 19, 2016, from https://www.theguardian.com/world/2012/mar/22/chinaseychelles-indian-fears-encirclement.

Rajan, D. S. (2014, February). The Unfolding China's Indian Ocean Strategy (Paper No. 5646). Retrieved May 30, 2016, from South Asia Analysis Group website: www.southasiaanalysis.org/node/1455

Roy, S. (2015, Jul. 23). New land law in Maldives gives India china chills. The Indian Express. Retrieved May 14, 2016, from http://indianexpress.com/article/india/india-others/new-land-lawin-maldives-gives-india-china-chills/

Sakhuja, V. (2005, Feb. 8). Indian Naval Diplomacy: Post Tsunami, Institute of Peace and Conflict Studies. Retrieved from www.ipcs.org/.../navy/indian-naval-diplomacy-post-tsunami1640.html

Samaranayake, N. (2015, Mar. 31). India's Key to Sri Lanka: Maritime Infrastructure Development. The Diplomat. Retrieved May 14, 2016, from http:/ / thediplomat.com/2015/03/indias-key-to-sri-lankamaritime-infrastructure-development/ 
Scholtens, J., \& Kadirgamar, A. (2014, November 04). No Country for Small Fishers. The Hindu. Retrieved April 25, 2015, from http://www.thehindu.com/opinion/op-ed/no-country-for-smallfishers/article6561568.ece

Small Island Developing States, available. (n.d.). In Wikipedia. Retrieved May 09, 2016, from https://en.wikipedia.org/ wiki/ Small_Island_Developing_States

Sri Lanka Wants to Renew Colombo-Tuticorin Ferry Service. (n.d.). World Maritime News. Retrieved June 15, 2015, from http:// worldmaritimenews.com/archives/163865/sri-lanka-wants-to-renewcolombo-tuticorin-ferry-service/

Taliban storms Karachi harbor (2013, March 20). The Dawn. Retrieved May 21, 2016, from www.dawn.com/news/11316549.

Tharoor, S. (2015, July 13). A Kerala Port with Adani. Why That's a Good Thing. NDTV. Retrieved June 19, 2016, from http:// www.ndtv.com/ opinion/a-kerala-port-with-adani-why-thats-a-good-thing-780831

Triverdi, V. (2015, Jul. 18). The Blue Economy, Green Gain. The Indian Express. Retrieved June 03, 2016, from http:// indianexpress.com/ article/opinion/columns/blue-economy-green-gain/

Venkatesan, J. (2013, August 31). Kachchatheevu was not ceded to Sri Lanka, Centre tells court. The Hindu. Retrieved June 21, 2015, from http://www.thehindu.com/news/national/kachchatheevu-was-notceded-to-sri-lanka-centre-tells-court/article5076961.ece

Zaman, S. S. (2014, July 08). Bangladesh wins another legal battle in the bay. Dhaka Tribune. Retrieved June 07, 2016, from http://archive.dhakatribune.com/bangladesh/2014/jul/08/banglad esh-gets-19467-square-km

Zorawar, D. (2015). Indian perceptions of china's maritime Silk Road idea. Journal of Defence Studies, 8(4), 133-148. 